\title{
An exploratory study of the associations between maternal iron status in pregnancy and childhood wheeze and atopy
}

\author{
Bright I. Nwaru ${ }^{1}$, Helen Hayes ${ }^{2}$, Lorraine Gambling ${ }^{2}$, Leone C. A. Craig ${ }^{3}$, Keith Allan ${ }^{4}$, Nanda Prabhu ${ }^{4}$, \\ Steven W. Turner ${ }^{4}$, Geraldine McNeill ${ }^{3}$, Maijaliisa Erkkola ${ }^{5}$, Anthony Seaton ${ }^{6}$, Harry J. McArdle ${ }^{2}$ and \\ Graham Devereux ${ }^{4 *}$ \\ ${ }^{1}$ Allergy and Respiratory Research Group, Centre for Population Health Sciences, University of Edinburgh, Edinburgh, UK \\ ${ }^{2}$ Rowett Institute of Nutrition and Health, University of Aberdeen, Aberdeen AB25 2ZG, UK \\ ${ }^{3}$ Public Health Nutrition Group, University of Aberdeen, Aberdeen AB25 2ZG, UK \\ ${ }^{4}$ Department of Child Health, Royal Aberdeen Children's Hospital, University of Aberdeen, Aberdeen AB25 2ZG, UK \\ ${ }^{5}$ Division of Nutrition, Department of Food and Environmental Sciences, University of Helsinki, Helsinki, Finland \\ ${ }^{6}$ Department of Environmental and Occupational Medicine, University of Aberdeen, Aberdeen AB25 2ZG, UK
}

(Submitted 24 April 2014 - Final revision received 11 August 2014 - Accepted 28 August 2014 - First published online 24 October 2014)

\begin{abstract}
Maternal nutritional status during pregnancy has been reported to be associated with childhood asthma and atopic disease. The Avon Longitudinal Study of Parents and Children has reported associations between reduced umbilical cord Fe status and childhood wheeze and eczema; however, follow-up was short and lung function was not measured. In the present study, the associations between maternal Fe status during pregnancy and childhood outcomes in the first 10 years of life were investigated in a subgroup of 157 mother-child pairs from a birth cohort with complete maternal, fetal ultrasound, blood and child follow-up data. Maternal Fe intake was assessed using FFQ at 32 weeks of gestation and $\mathrm{Hb}$ concentrations and serum Fe status (ferritin, soluble transferrin receptor and TfR-F (transferrin receptor:ferritin) index) were measured at 11 weeks of gestation and at delivery. Maternal Fe intake, Hb concentrations and serum Fe status were found to be not associated with fetal or birth measurements. Unit increases in first-trimester maternal serum TfR concentrations (OR 1.44, 95\% CI 1.05, 1.99) and TfR-F index (OR 1.42, $95 \%$ CI 1.10, 1.82) (i.e. decreasing Fe status) were found to be associated with an increased risk of wheeze, while unit increases in serum ferritin concentrations (i.e. increasing Fe status) were found to be associated with increases in standardised mean peak expiratory flow (PEF) $(\beta 0 \cdot 25,95 \% \mathrm{CI} 0 \cdot 09,0 \cdot 42)$ and forced expiratory volume in the first second $\left(\mathrm{FEV}_{1}\right)(\beta 0 \cdot 20,95 \% \mathrm{CI} 0 \cdot 08,0 \cdot 32)$ up to 10 years of age. Increasing maternal serum TfR-F index at delivery was found to be associated with an increased risk of atopic sensitisation (OR 1.35, $95 \%$ CI 1.02, 1.79). The results of the present study suggest that reduced maternal Fe status during pregnancy is adversely associated with childhood wheeze, lung function and atopic sensitisation, justifying further studies on maternal Fe status and childhood asthma and atopic disease.
\end{abstract}

Key words: Iron: Pregnancy: Children: Wheeze: Atopy: Lung function

The associations between birth anthropometry and subsequent wheeze and atopy have been interpreted as evidence of in utero nutritional influences on fetal airway and immune development ${ }^{(1-4)}$. This concept is supported by the associations between reduced birth weight and reduced lung function in later life, suggesting that suboptimal fetal growth and nutrition increase the risk of airflow obstruction in later life ${ }^{(5-7)}$. Studies on fetal ultrasound measurements provide more direct evidence of the importance of fetal growth in the development of wheeze, asthma and lung function ${ }^{(8,9)}$.

There are now many reports of the associations between childhood wheeze, asthma, and atopic disease and maternal nutritional status during pregnancy, particularly related to antioxidants, PUFA/lipids and vitamin $\mathrm{D}^{(10-12)}$. Although highlighted by animal models and a single human study, the potential role of maternal Fe status during pregnancy in the development of childhood wheeze, asthma and lung function remains relatively unexplored. In rodents, Fe deficiency during pregnancy induces hypertension in the offspring, coupled with changes in lipid metabolism and adult obesity $^{(13)}$. It has also been suggested that changes occur in lung structure, without any expansion of the alveoli (L Gambling and HJ McArdle, unpublished results).

The Avon Longitudinal Study of Parents and Children (ALSPAC) has reported associations between reduced umbilical cord Fe status and childhood wheeze; however, it

Abbreviations: ALSPAC, Avon Longitudinal Study of Parents and Children; FEV $_{1}$, forced expiratory volume in the first second; FVC, forced vital capacity; PEF, peak expiratory flow; sTfR, soluble transferrin receptor.

*Corresponding author: G. Devereux, fax +44 1224 438469, email g.devereux@abdn.ac.uk 
was concluded that this could have been the consequence of multiple analyses ${ }^{(14)}$. Moreover, the study had a relatively short follow-up duration and lacked lung function data. Given the relative ease of Fe supplementation during pregnancy, these novel findings justify further studies on the role of $\mathrm{Fe}$ in the development of lung function, wheeze, asthma and atopy.

The present study investigated the associations of maternal Fe status during pregnancy with fetal growth, birth anthropometry, childhood wheeze/atopy and lung function up to 10 years of age in a subgroup of children from the SEATON (Study of Eczema and Asthma To Observe the influence of Nutrition) birth cohort. This cohort was established to prospectively investigate the associations between maternal nutritional status during pregnancy and childhood asthma and atopic disease ${ }^{(15)}$.

\section{Experimental methods Study design}

Between 1997 and 1999, pregnant women were recruited to the SEATON. Maternal dietary intake and nutritional status were assessed, and the first- and second-trimester fetal measurement data were collected. Singleton children were followed up using a postal questionnaire ${ }^{(15)}$ at 1, 2, 5 and 10 years of age. At 5 and 10 years of age, the children were invited to attend a clinical assessment. The present study was approved by the North of Scotland Research Ethics Committee (08/S0802/19), and written parental consent was obtained and children gave verbal and/or written assent.

\section{Recruitment}

Complete details of recruitment have been described previously $^{(15)}$. A total of 2000 healthy pregnant women attending an antenatal clinic for a routine dating ultrasound scan, at median 11 (interquartile range 8-12) weeks of gestation, were recruited. There was no selection for asthma, atopic disease, anaemia or Fe status, and the recruited women were mostly representative of the local obstetric population ${ }^{(15)}$. At enrolment, an interviewer administered a questionnaire; atopic status was ascertained by skin-prick testing, and a non-fasting blood sample was collected. At 32 weeks of gestation, habitual dietary intake during the previous 3 months was assessed using a semi-quantitative $\mathrm{FFQ}^{(16)}$. In forty women of childbearing age, the rank correlation coefficient for Fe intake determined by this FFQ and $4 \mathrm{~d}$ weighed records was $0 \cdot 60(P<0 \cdot 001)^{(16)}$.

\section{Fetal measurements}

Details regarding fetal measurements have been described elsewhere ${ }^{(9)}$, and these measurements were recorded as part of routine antenatal care using an ATL (Ultramark 4A) or Toshiba (SSA-240A or SSA-340A) ultrasound scanner. The crown-rump length was measured during the first-trimester scan, and the femur length and biparietal diameter (inner-outer) were measured during the second-trimester scan. Fetal and neonatal measurements are expressed as $z$-scores ${ }^{(17,18)}$.

\section{Outcome assessments}

A questionnaire based on the International Study of Asthma and Allergy in Children format was posted to the parents of cohort children at $1,2,5$ and 10 years of age. Doctorconfirmed asthma was defined as an affirmative response to the following two questions: 'Has your child ever had asthma?' and 'Was this confirmed by a doctor?'. Similar questions were asked about 'doctor-diagnosed eczema' and 'doctor-diagnosed hay fever'. At 5 and 10 years of age, the cohort children were invited to attend a detailed assessment. This included spirometry using a pneumotachograph (21/20; Vitalograph) with incentive software (Spirotrac IV version 4.22; Vitalograph) and application of standard quality control ${ }^{(19)}$ Spirometric variables are expressed as $z$-scores ${ }^{(20)}$. Atopic status was determined by skin-prick testing (dust mite, cat and dog allergens, grass pollen, egg and peanut; ALK Abello). Atopic sensitisation was defined as a mean wheal diameter $\geq 3 \mathrm{~mm}$ when compared with the negative control.

\section{Determination of maternal iron status}

Ferritin was used as a measure of Fe stores and serum soluble transferrin receptor (sTfR) was used as an indicator of Fe deficiency; both are more sensitive indicators of Fe status than dietary $\mathrm{Fe}$ intake or $\mathrm{Hb}$ concentration ${ }^{(21,22)}$. Maternal blood samples were collected at recruitment (11 weeks of gestation) and at delivery. As financial considerations only permitted analysis of a limited number of blood samples, the analysis was restricted to mother-child pairs with complete datasets during pregnancy (blood samples and fetal scans) and up to 10 years of age (questionnaire data at 1, 2, 5 and 10 years and spirometric measurement data at 5 and 10 years). Maternal serum ferritin and sTfR concentrations were quantified using ELISA (DE1872; Demeditec Diagnostics and Human sTfR Quantikine IVD, DTFR; R\&D Systems, respectively). In both assays, $20 \mu$ l of serum were used and samples were run in duplicate; Western blotting confirmed negligible protein degradation during storage at $-80^{\circ} \mathrm{C}$. All plates contained both intra- and inter-plate quality controls and were assayed according to the manufacturers' instructions. The sTfR:log(ferritin) ratio (TfR-F index) was calculated as described by Cook et al. ${ }^{(23)}$. Decreasing ferritin concentrations and increasing sTfR concentrations and TfR-F index are evidence of declining Fe status.

\section{Statistical analyses}

Differences in enrolment characteristics between women with serum Fe measurement data and those without these data were analysed using the $\chi^{2}$ test. Student's $t$ tests and ANOVA were used to relate maternal serum $\mathrm{Fe}$ status to maternal enrolment characteristics. The exposures of interest were unit increases in maternal serum ferritin concentrations, STfR concentrations and the TfR-F index at 11 weeks of gestation and at delivery. Maternal dietary Fe and Fe supplement intake values were summated and energy was adjusted using the residual $\operatorname{method}^{(24)}$ and divided into thirds. Linear regression was used to model the associations 
between maternal Fe intake, serum Fe status at recruitment and at delivery, and first- and second-trimester fetal measurements and birth anthropometry. The main outcomes were the longitudinal development of wheeze, 'doctor-diagnosed asthma, atopic eczema, and hay fever', atopic sensitisation and lung function (peak expiratory flow (PEF), forced expiratory volume in the first second $\left(\mathrm{FEV}_{1}\right)$ and forced vital capacity (FVC)) up to 10 years of age. The associations between maternal Fe intake and serum Fe status and the development of wheezing symptoms and lung function were investigated using generalised estimating equations with an exchangeable correlation structure. The associations between maternal Fe intake and serum Fe status and the development of asthma, atopic eczema, hay fever and atopic sensitisation were modelled using discrete-time hazard models. Unadjusted and adjusted results were computed for all analyses. The adjusted results included maternal smoking status, atopic status, age and socio-economic status (Scottish Index of Multiple Deprivation) and child sex and gestational age at birth. These potential confounding variables were chosen based on conceptual evidence and by statistical tests (i.e. if the variables achieved $P<0.25$ in a univariate association with any of the endpoints) ${ }^{(25)}$. Interaction terms between serum Fe status and time (i.e. age when outcomes were ascertained) in relation to wheeze as well as lung function endpoints were included in the models to investigate whether the influence of maternal serum Fe status on the outcomes was time dependent. Bonferroni adjustment was used for the correction of multiple testing. The analyses were performed using Stata 11 (Stata Statistical Software: Release 11; StataCorp LP).

\section{Results}

Of the 1924 women with a singleton birth, serum Fe measurement data were available for 157 women at 11 weeks of gestation and at delivery. The mean concentrations of serum ferritin and sTfR at 11 weeks of gestation were $28.4(\mathrm{sD} 43.4) \mathrm{ng} / \mathrm{ml}$ and $12.0(\mathrm{SD} 3.0) \mathrm{nmol} / \mathrm{l}$, respectively; the corresponding values at delivery were $10 \cdot 2(\mathrm{SD} 19 \cdot 2) \mathrm{ng} / \mathrm{ml}$ and $18.8(\mathrm{SD} 17 \cdot 6) \mathrm{nmol} / \mathrm{l}$, respectively. Women without serum Fe measurement data were more likely to smoke, were younger, and were of lower socio-economic status when compared with women with Fe measurement data (Table 1). Maternal smoking status and atopic status were not associated with serum ferritin concentrations, sTfR concentrations and TfR-F index at 11 weeks of gestation and at delivery (Table 1). There was no difference in dietary Fe intake (13.9 (sD 4.98) v. $13.6(\mathrm{sD} 3.77) \mathrm{mg} / \mathrm{d})$ or Fe supplement use $(37 v .41 \%, P=0.33)$ in women with or without $\mathrm{Fe}$ measurement data. Maternal total Fe intake quantified at 32 weeks of gestation was not associated with serum Fe indices at 11 weeks of gestation, but was weakly associated with maternal serum Fe indices at delivery (Spearman's $\rho$ for ferritin $0 \cdot 27, P=0.002 ;$ sTfR $-0 \cdot 29, P<0 \cdot 001 ;$ TfR-F $-0 \cdot 29, P=0.001$; and $\mathrm{Hb} 0 \cdot 18, P=0.023)$. At 32 weeks of gestation, fifty-eight (37\%) women were found to be taking Fe supplements. When compared with women not using Fe supplements, in women using Fe supplements, Fe supplement use was associated with reduced Fe status at recruitment (11 weeks of gestation), but with increased Fe status at delivery (Fig. 1).

Maternal serum Fe status (ferritin, sTfR and sTfR-F index) at 11 weeks of gestation was not significantly associated with any of the first- or second-trimester ultrasound measurements or with birth measurements (Table 2).

The prevalence of wheeze, asthma, eczema, hay fever and atopic sensitisation at 10 years of age is summarised in Table 3.

Maternal dietary $\mathrm{Fe}$ intake (including and excluding $\mathrm{Fe}$ supplement intake) and Fe supplement use at 32 weeks of gestation were not associated with any fetal or birth measurement or with asthma, wheeze, lung function or atopic outcomes up to 10 years of age (data not shown).

\section{Longitudinal associations with maternal serum iron status at 11 weeks of gestation}

In unadjusted and adjusted models, maternal serum ferritin concentrations at 11 weeks of gestation were found to be not associated with wheeze, hay fever, atopy, atopic eczema and asthma endpoints (Table 4). A unit increase in maternal serum ferritin concentrations at 11 weeks of gestation was associated with increased standardised lung function measurements (PEF, $\mathrm{FEV}_{1}$ and $\mathrm{FVC}$ ) up to 10 years of age. In models that included interaction terms, a significant positive interaction was found between maternal serum ferritin concentrations at 11 weeks of gestation and time (age when children's lung function was measured) in relation to lung function measurements (Table 4). In adjusted models, a unit increase in maternal STfR concentrations (i.e. reduced Fe status) at 11 weeks of gestation was found to be associated with an increased OR of 'wheeze in the past year' and 'wheeze without cold in the past year', but no association was found with 'doctor-diagnosed asthma, hay fever, and eczema', atopic sensitisation or lung function. In adjusted models, increasing sTfR-F index (i.e. reduced Fe status) was found to be associated with an increased risk of 'wheeze in the past year' and 'wheeze without cold in the last year', but no association was found with any other outcome (Table 4). After Bonferroni adjustment for multiple testing, the association between maternal first-trimester serum ferritin concentrations and childhood $\mathrm{FEV}_{1}$ remained significant. Dichotomisation of women into those with and without sufficient serum ferritin concentrations $(\geq 15$ and $<15 \mu \mathrm{g} / \mathrm{ml})$ and Hb concentrations ( $\geq 105$ and $<105 \mathrm{~g} / \mathrm{l} ; \geq 10.5$ and $<10.5 \mathrm{~g} / \mathrm{dl}$ ) at 11 weeks of gestation was performed and their associations with childhood outcomes were examined (online supplementary Tables S1 and S2). There were no significant associations between dichotomised Fe status and childhood outcomes; moreover, we lacked sufficient power to detect statistically meaningful effect estimates or undertake any confounder adjustments.

\section{Longitudinal associations with maternal serum iron status at delivery}

Maternal serum ferritin and sTfR concentrations at delivery were not associated with any of the wheeze, asthma, atopic 
Table 1. Maternal serum ferritin concentrations at recruitment (11 weeks of gestation) and at delivery by maternal and neonatal characteristics (Mean values and standard deviations; number of children and percentages)

\begin{tabular}{|c|c|c|c|c|c|c|c|c|c|c|c|c|c|}
\hline \multirow[b]{3}{*}{ Covariates } & \multicolumn{7}{|c|}{ Women with or without Fe measurement data } & \multirow{2}{*}{\multicolumn{3}{|c|}{$\begin{array}{c}\text { Maternal ferritin } \\
\text { concentrations at } \\
11 \text { weeks of gestation } \\
(\mathrm{ng} / \mathrm{ml})(n 157)\end{array}$}} & \multirow{2}{*}{\multicolumn{3}{|c|}{$\begin{array}{l}\text { Maternal ferritin } \\
\text { concentrations at } \\
\text { delivery }(\mathrm{ng} / \mathrm{ml}) \\
(n 157)\end{array}$}} \\
\hline & \multicolumn{2}{|c|}{$\begin{array}{c}\text { All } \\
(n \text { 1924) }\end{array}$} & \multicolumn{2}{|c|}{$\begin{array}{c}\text { Without Fe } \\
\text { measurement } \\
\text { data }(n 1767)\end{array}$} & \multicolumn{2}{|c|}{$\begin{array}{c}\text { With Fe } \\
\text { measurement } \\
\text { data }(n 157)\end{array}$} & \multirow[b]{2}{*}{$P^{*}$} & & & & & & \\
\hline & $n$ & $\%$ & $n$ & $\%$ & $n$ & $\%$ & & Mean & SD & $P \dagger$ & Mean & SD & $P \dagger$ \\
\hline $\begin{array}{l}\text { Maternal smoking status } \\
\text { during pregnancy }\end{array}$ & & & & & & & 0.002 & & & 0.434 & & & 0.185 \\
\hline No & 1357 & 71 & 1229 & 70 & 128 & 82 & & $28 \cdot 3$ & $44 \cdot 5$ & & $10 \cdot 7$ & $10 \cdot 1$ & \\
\hline Yes & 566 & 29 & 537 & 30 & 29 & 18 & & $21 \cdot 6$ & $18 \cdot 5$ & & $7 \cdot 6$ & $7 \cdot 5$ & \\
\hline Maternal atopic status & & & & & & & 0.199 & & & 0.643 & & & 0.197 \\
\hline No & 1134 & 59 & 1049 & 59 & 85 & 54 & & $27 \cdot 7$ & $48 \cdot 1$ & & $10 \cdot 5$ & $10 \cdot 8$ & \\
\hline Yes & 789 & 41 & 717 & 41 & 72 & 46 & & $26 \cdot 1$ & $28 \cdot 3$ & & $9 \cdot 7$ & $8 \cdot 3$ & \\
\hline $\begin{array}{l}\text { Maternal age at } \\
\text { recruitment (years) }\end{array}$ & & & & & & & $<0.001$ & & & $0 \cdot 787$ & & & 0.432 \\
\hline$\leq 25$ & 469 & 24 & 450 & 30 & 19 & 14 & & $21 \cdot 3$ & 21.9 & & $13 \cdot 8$ & $15 \cdot 4$ & \\
\hline $26-30$ & 674 & 35 & 611 & 41 & 63 & 46 & & 22.9 & $20 \cdot 1$ & & $9 \cdot 1$ & $7 \cdot 8$ & \\
\hline $31-34$ & 485 & 25 & 431 & 29 & 54 & 40 & & $20 \cdot 2$ & $18 \cdot 2$ & & $9 \cdot 9$ & $10 \cdot 5$ & \\
\hline Maternal SIMD at recruitment & & & & & & & 0.009 & & & 0.481 & & & 0.667 \\
\hline 1st quintile (least deprived) & 835 & 43 & 750 & 42 & 85 & 54 & & $23 \cdot 2$ & $21 \cdot 7$ & & $10 \cdot 5$ & $10 \cdot 8$ & \\
\hline 2nd quintile & 515 & 27 & 474 & 27 & 41 & 26 & & $22 \cdot 4$ & $17 \cdot 1$ & & $11 \cdot 2$ & $9 \cdot 6$ & \\
\hline 3rd quintile & 183 & 10 & 168 & 10 & 15 & 10 & & $15 \cdot 2$ & 12.9 & & $6 \cdot 2$ & 3.4 & \\
\hline 4th quintile & 236 & 12 & 225 & 13 & 11 & 7 & & $30 \cdot 3$ & 21.4 & & $7 \cdot 7$ & 4.8 & \\
\hline 5th quintile (most deprived) & 155 & 8 & 150 & 8 & 5 & 3 & & $14 \cdot 3$ & $12 \cdot 8$ & & $10 \cdot 4$ & $7 \cdot 6$ & \\
\hline Crown-heel length & & & & & & & 0.048 & & & 0.94 & & & 0.534 \\
\hline 1st quarter & 456 & 24 & 429 & 26 & 27 & 17 & & $20 \cdot 4$ & 21.4 & & $12 \cdot 4$ & $16 \cdot 3$ & \\
\hline 2nd quarter & 619 & 32 & 562 & 34 & 57 & 37 & & $22 \cdot 4$ & $17 \cdot 9$ & & $9 \cdot 8$ & $7 \cdot 3$ & \\
\hline 3rd quarter & 302 & 16 & 267 & 16 & 35 & 22 & & $23 \cdot 8$ & $19 \cdot 2$ & & $11 \cdot 0$ & $10 \cdot 6$ & \\
\hline 4th quarter & 440 & 23 & 403 & 24 & 37 & 24 & & 22.9 & $22 \cdot 3$ & & $8 \cdot 3$ & 6.9 & \\
\hline Gestational age at birth & & & & & & & 0.09 & & & 0.891 & & & 0.477 \\
\hline 1st quarter & 394 & 20 & 369 & 22 & 25 & 16 & & 22.9 & $22 \cdot 5$ & & $13 \cdot 0$ & $16 \cdot 7$ & \\
\hline 2nd quarter & 388 & 20 & 355 & 21 & 33 & 21 & & $23 \cdot 2$ & $21 \cdot 0$ & & $8 \cdot 0$ & 6.5 & \\
\hline 3rd quarter & 510 & 27 & 454 & 27 & 56 & 36 & & 23.4 & $21 \cdot 2$ & & $10 \cdot 2$ & 9.5 & \\
\hline 4th quarter & 538 & 28 & 495 & 30 & 43 & 27 & & $20 \cdot 2$ & $15 \cdot 5$ & & $10 \cdot 2$ & $7 \cdot 5$ & \\
\hline Birth order & & & & & & & 0.221 & & & 0.859 & & & 0.044 \\
\hline 0 & 943 & 49 & 857 & 49 & 86 & 55 & & 24.4 & 21.8 & & $10 \cdot 3$ & $9 \cdot 0$ & \\
\hline 1 & 671 & 35 & 619 & 35 & 52 & 33 & & $20 \cdot 1$ & $16 \cdot 0$ & & $8 \cdot 2$ & $7 \cdot 1$ & \\
\hline$>1$ & 310 & 16 & 291 & 16 & 19 & 12 & & $19 \cdot 4$ & $20 \cdot 0$ & & $16 \cdot 1$ & $17 \cdot 5$ & \\
\hline Sex of child & & & & & & & 0.505 & & & 0.418 & & & 0.218 \\
\hline Male & 960 & 50 & 891 & 51 & 75 & 48 & & $30 \cdot 0$ & $52 \cdot 3$ & & $11 \cdot 1$ & 9.9 & \\
\hline Female & 940 & 49 & 858 & 49 & 82 & 52 & & 24.5 & $27 \cdot 3$ & & $9 \cdot 3$ & 9.6 & \\
\hline
\end{tabular}

SIMD, Scottish Index of Multiple Deprivation.

${ }^{*} P$ value for Pearson's $\chi{ }^{2}$ test.

†The $t$ test for covariates with two categories and ANOVA for covariates with more than two categories.

or lung function parameters measured up to 10 years of age (Table 5). Increasing sTfR-F index at delivery was associated with an increased risk of atopic sensitisation $(P=0 \cdot 037)$; an increased risk of 'doctor-diagnosed eczema' was of borderline significance $(P=0.068)$ after adjustment for confounders. Further analyses with dichotomised maternal serum ferritin and $\mathrm{Hb}$ concentrations revealed no significant associations with childhood outcomes (online supplementary Tables S1 and S2).

\section{Discussion}

In the present exploratory study, no association was found between first-trimester maternal Fe status and fetal ultrasound and birth measurements. However, we report for the first time that decreasing first-trimester maternal serum ferritin concentrations (i.e. reduced $\mathrm{Fe}$ stores) are associated with reduced
$\mathrm{FEV}_{1}, \mathrm{FVC}$ and PEF in children up to 10 years of age and that increasing maternal serum STfR concentrations and TfR-F index (i.e. Fe deficiency) are associated with an increased risk of childhood wheeze up to 10 years of age. A significant positive interaction was found between firsttrimester maternal ferritin status and children's age, suggesting that the magnitude of the adverse effect of low maternal Fe status during pregnancy increases as children grow. In addition, an adverse association was observed between reduced maternal Fe status at delivery (increasing sTfR-F index) and an increased risk of atopic sensitisation in children.

The associations found in the present study are consistent with the notion that maternal Fe status during pregnancy influences fetal lung development such that children born to mothers with lower Fe status are established on a suboptimal lung developmental trajectory characterised by reduced lung function during the first decade of life. The associations 


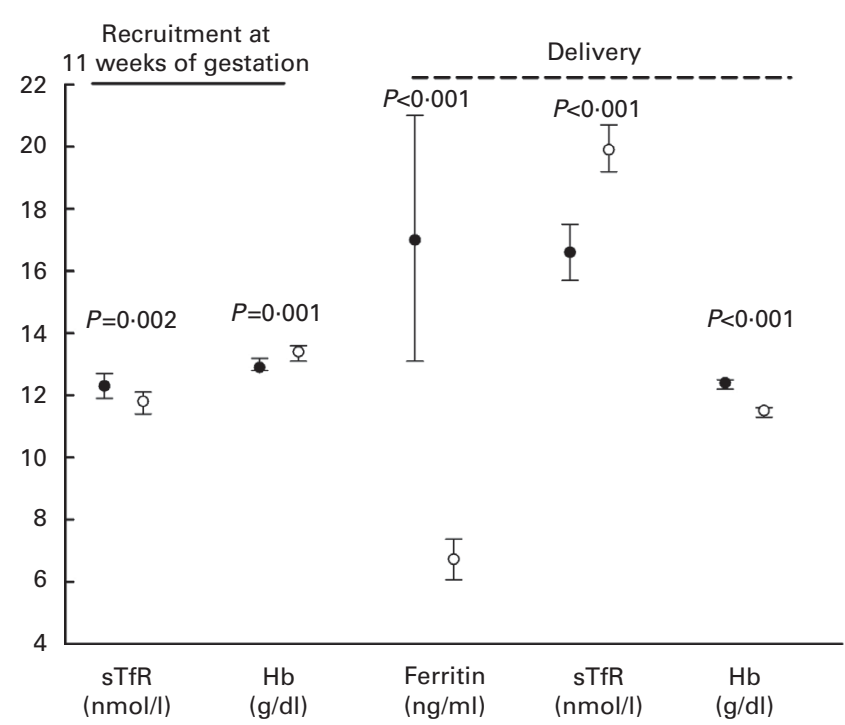

Fig. 1. Iron status (soluble transferrin receptor, $\mathrm{Hb}$ and ferritin) of women using $(\bullet)$ and not using $(O)$ iron supplements. sTfR, soluble transferrin receptor.

found in the present study between suboptimal maternal Fe status and lung function and wheeze are consistent with the results of longitudinal studies that have tracked neonatal lung function and shown that children established on a suboptimal lung growth trajectory are more likely to wheeze ${ }^{(26)}$ The lack of an association with maternal $\mathrm{Fe}$ intake and $\mathrm{Hb}$ concentrations is not surprising, as it is well established that neither is a good indicator of Fe status.

Fetal lung development occurs in a relatively hypoxic environment, and in animal models, Fe has been found to be involved in airway development. Chelation of Fe by desferrioxamine in ex vivo lung buds from embryonic day mice has been found to reduce the vascular network surrounding the developing lung buds and to reduce epithelial branching ${ }^{(27)}$. $\mathrm{FeCl}_{3}$ reverses the inhibitory effects of chelation. This animal study has suggested that Fe influences airway development through regulatory effects on vascular endothelial growth factor signalling and up-regulation of hypoxia-inducible factor- $1 \alpha$. It also supports findings from the present study that suboptimal Fe status adversely affects fetal airway development. Women given Fe supplements during pregnancy have a lower risk of preterm birth and give birth to larger babies $^{(22)}$. In addition, first-trimester $\mathrm{Fe}$ intake is also positively associated with birth outcome ${ }^{(28)}$. Intake later in pregnancy does not exhibit this association ${ }^{(29)}$. These results are consistent with the importance of $\mathrm{Fe}$ in the regulation of differentiation rather than in proliferation. Although associations between maternal $\mathrm{Fe}$ status and childhood wheeze, lung function and atopic outcomes were found in the present study, associations with fetal measurements or birth anthropometry could not be demonstrated; this may be a consequence of a small study sample size.

We are aware of one study that has investigated fetal Fe status in relation to childhood wheeze, asthma and atopic outcomes. In the ALSPAC, umbilical cord Fe concentration was found to be inversely associated with childhood wheeze

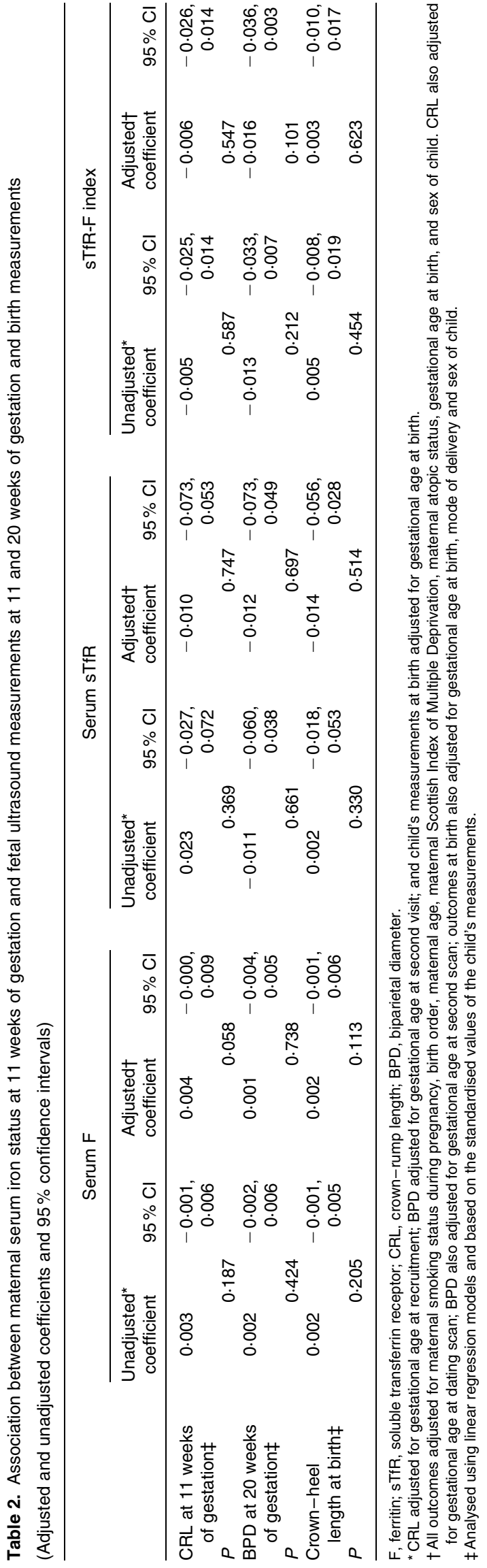


Table 3. Prevalence of asthma and atopic outcomes in the 157 study children at 10 years of age

(Number of children and percentages)

\begin{tabular}{lcr}
\hline & $n$ & $\%$ \\
\hline Ever had wheeze & 33 & 21 \\
Wheeze in the last 12 months & 14 & 9 \\
Wheeze in the absence of a cold in the last 12 months & 10 & 6 \\
Ever had asthma & 23 & 15 \\
Treatment for asthma in the last year & 16 & 10 \\
Ever had eczema & 39 & 26 \\
Ever had hay fever & 45 & 30 \\
Atopic sensitisation & 27 & 37 \\
\hline
\end{tabular}

* Skin-prick testing was done in seventy-three children.

up to 42 months of age ${ }^{(14)}$. Although the study concluded that fetal exposure to Fe might possibly influence the risk of wheezing in early childhood, caution was advised because of the multiple analyses conducted. The associations between maternal Fe status and childhood wheeze observed in the present study are consistent with those reported by the $\operatorname{ALSPAC}^{(14)}$, and the association between maternal firsttrimester serum ferritin concentrations and $\mathrm{FEV}_{1}$ remained significant after Bonferroni adjustment. In the present study pregnant women who were Fe deficient appeared to have been more likely to use Fe supplements, leading to improved Fe status at delivery; however, we were unable to find any association between Fe supplementation and childhood outcomes, probably because only fifty-eight of the 157 women took a variety of Fe supplements during pregnancy.

A further finding of the ALSPAC was an inverse association between umbilical cord Fe status and childhood eczema up to 30 months of age, but was qualified because of the multiple analyses performed. In the present study, a borderline significant association was observed between low maternal Fe status at delivery (sTfR-F index) and 'doctor-diagnosed eczema' in the first decade of life. Although the differences in significance between the present study and the ALSPAC may reflect differences in sample size, in the present study, maternal Fe status at delivery (sTfR-F index) was inversely associated with childhood atopic sensitisation. Although the associations between maternal serum $\mathrm{Fe}$ status and atopic outcomes observed in the present study are consistent with those reported in the ALSPAC, adjustment for multiple testing resulted in the associations becoming non-significant in the ALSPAC.

The results of the present study suggest differential associations between maternal serum Fe status at pregnancy and childhood outcomes; while first-trimester Fe status was associated with childhood lung function and wheeze, maternal serum Fe status at delivery was associated with childhood atopic outcomes. This suggests that maternal Fe status at delivery possibly influences the first critical interactions between the infant's immune system and allergens that certainly commence soon after birth (if not earlier). In animal models, Fe has been found to promote T-helper-cell differentiation away from the Th2 phenotype. In murine models of airway eosinophilia, parenteral Fe supplementation has been found to be associated with reduced airway eosinophilia, airway hyper-responsiveness and reduced lung tissue IL- 4 , IL- 5 and
IL-13 concentrations ${ }^{(30,31)}$. The timing of any putative $\mathrm{Fe}$ supplementation is likely to be critically important in correcting deficiency-induced effects. Data showing that $\mathrm{Fe}$ deficiency-induced changes in the brain can be reversed by early, but not later, supplementation have been obtained from human subjects and monkeys ${ }^{(32-36)}$.

Several disparities are evident in the present study. A possible explanation for the absence of an association between maternal Fe intake and childhood outcomes is that the data on serum parameters most notably associated with outcomes were obtained at 11 weeks of gestation, whereas maternal dietary intake was quantified once at 32 weeks of gestation, and although women were asked to report their dietary intake in the previous 3 months, it is not possible to assume that $\mathrm{Fe}$ intake at 32 weeks of gestation is the same as that at the first trimester. Indeed, although maternal Fe intake at 32 weeks of gestation was correlated with maternal serum ferritin and STfR concentrations at delivery, there were no correlations with serum Fe parameters at 11 weeks of gestation. In the UK population, the prevalence of Fe-deficiency anaemia is estimated to be about $0-6 \%{ }^{(37)}$, although our own data from a cohort in Aberdeen suggest that the prevalence Fe deficiency may be much higher ${ }^{(38)}$. The observed association of sTfR concentrations with wheeze, but not with asthma, is likely to be a result of insufficient power to detect an association with asthma as substantially more children wheezed than had asthma. The differential associations between the parameters of Fe status (ferritin and sTfR) and childhood outcomes (lung function and wheeze/atopy) may be a consequence of $\mathrm{Fe}$ potentially influencing both fetal lung growth and immune responses. The consequence of low fetal tissue Fe stores (ferritin) by adversely affecting fetal lung growth is likely to be impaired lung function, whereas Fe deficiency (sTfR) by influencing immune differentiation and airway inflammation is likely to manifest as wheezing and atopic sensitisation.

The present study has a number of strengths and limitations. As this is an observational study, we cannot demonstrate causality. Even though adjustment for many potentially confounding factors was done, we cannot exclude the possibility of residual confounding by other unmeasured factors, although further analyses adjusting for alternative metrics of socio-economic status, e.g. parameters of maternal education, father's occupation-based social class, and maternal dietary intakes of vitamin E, vitamin D, Zn and Se, did not materially alter the reported associations. In the present study, maternal smoking status was found to be not significantly associated with Fe status; however, adjustment for maternal smoking status was done because there is some evidence that maternal smoking status is associated with increased cord blood $\mathrm{Hb}$ concentrations, sTfR concentrations, and sTfR-F index and decreased ferritin concentrations ${ }^{(39,40)}$. One of the strengths of the present study is that maternal Fe status was quantified at 11 weeks of gestation and at delivery using several parameters. Traditionally, maternal Fe status is inferred from $\mathrm{Hb}$ concentration and haematocrit measurement. These are not good indicators of Fe status, and more recently, serum ferritin concentration has been used as an indicator, as it reflects 
Table 4. Association between maternal serum iron status at 11 weeks of gestation and longitudinal development of asthma and atopic outcomes up to 10 years of age (Odds ratios and $95 \%$ confidence intervals)

\begin{tabular}{|c|c|c|c|c|c|c|c|c|c|c|c|c|c|c|c|c|c|c|}
\hline \multirow[b]{3}{*}{ Outcomes } & \multicolumn{6}{|c|}{ Serum F } & \multicolumn{6}{|c|}{ Serum sTfR } & \multicolumn{6}{|c|}{ sTfR-F index } \\
\hline & \multicolumn{2}{|c|}{ Unadjusted } & \multicolumn{2}{|c|}{ Adjusted* } & \multicolumn{2}{|c|}{$\begin{array}{l}\text { Interaction } \\
\text { with time }\end{array}$} & \multicolumn{2}{|c|}{ Unadjusted } & \multicolumn{2}{|c|}{ Adjusted* } & \multicolumn{2}{|c|}{$\begin{array}{l}\text { Interaction } \\
\text { with time }\end{array}$} & \multicolumn{2}{|c|}{ Unadjusted } & \multicolumn{2}{|c|}{ Adjusted* } & \multicolumn{2}{|c|}{$\begin{array}{l}\text { Interaction } \\
\text { with time }\end{array}$} \\
\hline & OR & $\begin{array}{c}95 \% \\
\mathrm{Cl}\end{array}$ & OR & $\begin{array}{c}95 \% \\
\mathrm{Cl}\end{array}$ & OR & $\begin{array}{c}95 \% \\
\mathrm{Cl}\end{array}$ & OR & $\begin{array}{c}95 \% \\
\mathrm{Cl}\end{array}$ & OR & $\begin{array}{l}95 \% \\
\mathrm{Cl}\end{array}$ & OR & $\begin{array}{c}95 \% \\
\mathrm{Cl}\end{array}$ & OR & $\begin{array}{c}95 \% \\
\mathrm{Cl}\end{array}$ & OR & $\begin{array}{c}95 \% \\
\mathrm{Cl}\end{array}$ & OR & $\begin{array}{c}95 \% \\
\mathrm{Cl}\end{array}$ \\
\hline $\begin{array}{c}\text { Wheeze in the } \\
\text { past yeart }\end{array}$ & 0.93 & $\begin{array}{r}0.64 \\
1.35\end{array}$ & 0.89 & $\begin{array}{c}0.59 \\
1.34\end{array}$ & 0.97 & $\begin{array}{c}0.87 \\
1.07\end{array}$ & $1 \cdot 25$ & $\begin{array}{c}0.93 \\
1.69\end{array}$ & 1.44 & $\begin{array}{c}1.05 \\
1.99\end{array}$ & 0.97 & $\begin{array}{r}0.91 \\
1.04\end{array}$ & $1 \cdot 36$ & $\begin{array}{c}1.06 \\
1.74\end{array}$ & 1.42 & $\begin{array}{c}1 \cdot 10 \\
1.82\end{array}$ & 0.94 & $\begin{array}{r}0.87 \\
1.01\end{array}$ \\
\hline$P$ & \multicolumn{2}{|c|}{0.689} & \multicolumn{2}{|c|}{0.59} & \multicolumn{2}{|c|}{0.551} & \multicolumn{2}{|c|}{0.142} & \multicolumn{2}{|c|}{0.025} & \multicolumn{2}{|c|}{0.453} & \multicolumn{2}{|c|}{0.015} & \multicolumn{2}{|c|}{0.007} & \multicolumn{2}{|c|}{0.078} \\
\hline $\begin{array}{l}\text { Wheeze without } \\
\text { cold in the } \\
\text { past yeart }\end{array}$ & 1.08 & $\begin{array}{c}0.74 \\
1.57\end{array}$ & 1.08 & $\begin{array}{c}0.72 \\
1.63\end{array}$ & 0.92 & $\begin{array}{c}0.79 \\
1.07\end{array}$ & 1.35 & $\begin{array}{c}0.92 \\
1.98\end{array}$ & 1.62 & $\begin{array}{c}1 \cdot 06 \\
2.46\end{array}$ & 0.92 & $\begin{array}{r}0.83 \\
1.02\end{array}$ & $1 \cdot 22$ & $\begin{array}{c}0.93 \\
1.58\end{array}$ & $1 \cdot 26$ & $\begin{array}{c}0.96 \\
1.66\end{array}$ & 0.99 & $\begin{array}{r}0.93 \\
1.06\end{array}$ \\
\hline$P$ & \multicolumn{2}{|c|}{0.702} & \multicolumn{2}{|c|}{0.702} & \multirow{2}{*}{\multicolumn{2}{|c|}{0.265}} & \multicolumn{2}{|c|}{0.123} & \multicolumn{2}{|c|}{0.024} & & 126 & & & & & & 777 \\
\hline $\begin{array}{l}\text { Doctor-diagnosed } \\
\text { eczemał }\end{array}$ & 0.73 & $\begin{array}{c}0.43 \\
1.25\end{array}$ & 0.69 & $\begin{array}{c}0.39 \\
1.22\end{array}$ & & & $1 \cdot 13$ & $\begin{array}{c}0.85 \\
1.51\end{array}$ & $1 \cdot 13$ & $\begin{array}{c}0.82 \\
1.55\end{array}$ & & 0.78 & $0.41,1.46$ & 0.80 & $0.44,1.4$ & & & \\
\hline$P$ & & & & 2 & & $-\S$ & & 01 & & & & $-\S$ & & & & & & $-\S$ \\
\hline $\begin{array}{l}\text { Doctor-diagnosed } \\
\text { hay feverł }\end{array}$ & $1 \cdot 14$ & $\begin{array}{l}0.80 \\
1.62\end{array}$ & $1 \cdot 13$ & $\begin{array}{r}0.77 \\
1.66\end{array}$ & & $-\S$ & 0.90 & $\begin{array}{r}0.55 \\
1.45\end{array}$ & 0.98 & $\begin{array}{c}0.57 \\
1.69\end{array}$ & & $-\S$ & 0.93 & $\begin{array}{c}0.51 \\
1.68\end{array}$ & 0.96 & $\begin{array}{c}0.55 \\
1.66\end{array}$ & & $-\S$ \\
\hline$P$ & & & & 21 & & & & 55 & & & & & & & & & & \\
\hline $\begin{array}{l}\text { Skin-prick test } \\
\text { positivity to } \\
\text { any allergen } \ddagger\end{array}$ & 0.42 & $\begin{array}{l}0 \cdot 15 \\
1 \cdot 21\end{array}$ & 0.38 & $\begin{array}{c}0 \cdot 12 \\
1 \cdot 14\end{array}$ & & $-\S$ & $1 \cdot 24$ & $\begin{array}{c}0.86 \\
1 \cdot 79\end{array}$ & 1.36 & $\begin{array}{l}0.91 \\
2.05\end{array}$ & & $-\S$ & $1 \cdot 21$ & $\begin{array}{c}0.93 \\
1.5- \\
73\end{array}$ & 1.20 & $\begin{array}{l}0.92 \\
1.57\end{array}$ & & $-\S$ \\
\hline$P$ & & & & 83 & & & & 41 & & & & & & & & & & \\
\hline $\begin{array}{l}\text { Doctor-diagnosed } \\
\text { asthmał }\end{array}$ & 1.00 & $\begin{array}{c}0.65 \\
1.53\end{array}$ & 0.92 & $\begin{array}{c}0.51 \\
1.69\end{array}$ & & & 0.92 & $\begin{array}{c}0.60 \\
1.41\end{array}$ & 0.96 & $\begin{array}{c}0.59 \\
1.58\end{array}$ & & & $1 \cdot 15$ & $\begin{array}{c}0.75 \\
1.77\end{array}$ & 1.40 & $\begin{array}{c}0.91 \\
2.15\end{array}$ & & \\
\hline $\begin{array}{l}P \\
\text { PEF+\| }\end{array}$ & & & & 99 & & $-\S$ & & & & & & $-\S$ & & & & & & $-\S$ \\
\hline Coefficient & & & & 25 & & .07 & & 04 & & & & .03 & & & & & & .01 \\
\hline $95 \% \mathrm{Cl}$ & 1.94 & 23.82 & 0.0 & 0.42 & 0.0 & 0.12 & -0.0 & 0.15 & -0.1 & 0.11 & -0.0 & $1,0.06$ & -0.1 & 0.12 & & $0 \cdot 13$ & $-0 . c$ & $3,0.04$ \\
\hline$P$ & & & & 03 & & 010 & & & & & & 129 & & & & & & 651 \\
\hline FEV ${ }_{1} \dagger \|$ & & & & & & & & & & & & & & & & & & \\
\hline Coefficient & & & & 20 & & .06 & & 03 & & & & .01 & & & & & & 0.01 \\
\hline $95 \% \mathrm{Cl}$ & 0.0 & $0 \cdot 16$ & 0.0 & 0.32 & 0.0 & 0.09 & -0.1 & 0.06 & -0.1 & 0.03 & -0.0 & $2,0.03$ & -0.1 & 0.07 & $-0 . c$ & 0.08 & -0.6 & $3,0.02$ \\
\hline$P$ & & & & 01 & & 004 & & & & & & 733 & & & & & & 545 \\
\hline FVC†\| & & & & & & & & & & & & & & & & & & \\
\hline Coefficient & & 7 & & 14 & & .04 & & 02 & & 05 & & 01 & & & & & & 0.01 \\
\hline $95 \% \mathrm{Cl}$ & 0.00 & 0.14 & 0.0 & 0.24 & 0.0 &, 0.08 & -0.0 & 0.05 & -0.1 & 0.02 & -0.0 & $1,0.03$ & -0.1 & 0.05 & $-0 . c$ & 0.06 & $-0 . c$ & $3,0.01$ \\
\hline$P$ & & & & 07 & & 005 & & & & & & 451 & & & & & & 244 \\
\hline
\end{tabular}

F, feritin; sTfR, soluble transferrin receptor; PEF, peak expiratory flow; $\mathrm{FEV}_{1}$, forced expiratory volume in the first second; FVC, forced vital capacity.

*Adjusted for maternal smoking status during pregnancy, birth order, maternal age, maternal Scottish Index of Multiple Deprivation, maternal atopic status, gestational age at birth and sex of child.

† Analysed using generalised estimating equations with an exchangeable correlation structure.

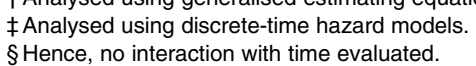

\|I Standardised $z$-score values of lung function measurements used in the analyses. 
Table 5. Association between serum iron status at delivery and longitudinal development of asthma and atopic outcomes up to 10 years of age (Odds ratios and $95 \%$ confidence intervals)

\begin{tabular}{|c|c|c|c|c|c|c|c|c|c|c|c|c|c|c|c|c|c|c|}
\hline \multirow[b]{3}{*}{ Outcomes } & \multicolumn{6}{|c|}{ Serum F } & \multicolumn{6}{|c|}{ Serum sTfR } & \multicolumn{6}{|c|}{ sTfR-F index } \\
\hline & \multicolumn{2}{|c|}{ Unadjusted } & \multicolumn{2}{|c|}{ Adjusted ${ }^{*}$} & \multicolumn{2}{|c|}{$\begin{array}{l}\text { Interaction } \\
\text { with time }\end{array}$} & \multicolumn{2}{|c|}{ Unadjusted } & \multicolumn{2}{|c|}{ Adjusted* } & \multicolumn{2}{|c|}{$\begin{array}{l}\text { Interaction } \\
\text { with time }\end{array}$} & \multicolumn{2}{|c|}{ Unadjusted } & \multicolumn{2}{|c|}{ Adjusted* } & \multicolumn{2}{|c|}{$\begin{array}{l}\text { Interaction } \\
\text { with time }\end{array}$} \\
\hline & OR & $\begin{array}{c}95 \% \\
\mathrm{Cl}\end{array}$ & OR & $\begin{array}{c}95 \% \\
\mathrm{Cl}\end{array}$ & OR & $\begin{array}{c}95 \% \\
\mathrm{Cl}\end{array}$ & OR & $\begin{array}{c}95 \% \\
\mathrm{Cl}\end{array}$ & OR & $\begin{array}{c}95 \% \\
\mathrm{Cl}\end{array}$ & OR & $\begin{array}{c}95 \% \\
\mathrm{Cl}\end{array}$ & OR & $\begin{array}{c}95 \% \\
\mathrm{Cl}\end{array}$ & OR & $\begin{array}{c}95 \% \\
\mathrm{Cl}\end{array}$ & OR & $\begin{array}{c}95 \% \\
\mathrm{Cl}\end{array}$ \\
\hline $\begin{array}{l}\text { Wheeze in the } \\
\text { past yeart }\end{array}$ & 0.73 & $\begin{array}{c}0.35 \\
1.52\end{array}$ & 0.81 & $\begin{array}{c}0.41 \\
1.63\end{array}$ & $1 \cdot 10$ & $\begin{array}{c}0.96 \\
1.26\end{array}$ & $1 \cdot 17$ & $\begin{array}{c}0.87 \\
1.57\end{array}$ & $1 \cdot 28$ & $\begin{array}{c}0.91 \\
1.79\end{array}$ & 0.97 & $\begin{array}{c}0.91 \\
1.04\end{array}$ & $1 \cdot 30$ & $\begin{array}{c}1.02 \\
1.65\end{array}$ & $1 \cdot 27$ & $\begin{array}{c}0.98 \\
1.64\end{array}$ & 1.00 & $\begin{array}{r}0.96 \\
1.05\end{array}$ \\
\hline$P$ & \multicolumn{2}{|c|}{0.405} & \multicolumn{2}{|c|}{0.567} & \multicolumn{2}{|c|}{0.164} & \multicolumn{2}{|c|}{0.312} & \multicolumn{2}{|c|}{0.152} & \multicolumn{2}{|c|}{0.346} & \multicolumn{2}{|c|}{0.035} & \multicolumn{2}{|c|}{0.067} & \multicolumn{2}{|c|}{0.879} \\
\hline $\begin{array}{l}\text { Wheeze without } \\
\text { cold in the } \\
\text { past year† }\end{array}$ & 0.68 & $\begin{array}{c}0.24 \\
1.91\end{array}$ & 0.75 & $\begin{array}{l}0 \cdot 25 \\
2 \cdot 24\end{array}$ & 1.31 & $\begin{array}{c}1.01 \\
1.71\end{array}$ & $1 \cdot 13$ & $\begin{array}{l}0.77 \\
1.68\end{array}$ & $1 \cdot 20$ & $\begin{array}{c}0.77 \\
1.87\end{array}$ & 0.94 & $\begin{array}{c}0.85 \\
1.04\end{array}$ & $1 \cdot 23$ & $\begin{array}{c}0.95 \\
1.60\end{array}$ & $1 \cdot 12$ & $\begin{array}{c}0.84 \\
1.49\end{array}$ & 1.01 & $\begin{array}{r}0.96 \\
1.06\end{array}$ \\
\hline$P$ & \multicolumn{2}{|c|}{0.463} & \multicolumn{2}{|c|}{0.606} & \multirow{2}{*}{\multicolumn{2}{|c|}{0.044}} & \multicolumn{2}{|c|}{0.527} & \multicolumn{2}{|c|}{0.422} & \multirow{2}{*}{\multicolumn{2}{|c|}{0.245}} & & & & & & 704 \\
\hline $\begin{array}{l}\text { Doctor-diagnosed } \\
\text { eczema } \neq\end{array}$ & 1.02 & $\begin{array}{c}0.75 \\
1.37\end{array}$ & 1.00 & $\begin{array}{c}0.71 \\
1.41\end{array}$ & & & 0.78 & $\begin{array}{c}0.55 \\
1.11\end{array}$ & 0.80 & $\begin{array}{c}0.55 \\
1.16\end{array}$ & & & $1 \cdot 15$ & $\begin{array}{c}0.93 \\
1.43\end{array}$ & $1 \cdot 24$ & $\begin{array}{c}0.98 \\
1.57\end{array}$ & & \\
\hline$P$ & & & & & & $\S$ & & & & & & $\S$ & & & & & & $-\S$ \\
\hline $\begin{array}{l}\text { Doctor-diagnosed } \\
\text { hay fever }\end{array}$ & 1.09 & $\begin{array}{r}0.76 \\
1.58\end{array}$ & $1 \cdot 11$ & $\begin{array}{c}0.74 \\
1.66\end{array}$ & & $\S$ & 0.78 & $\begin{array}{c}0.45 \\
1.37\end{array}$ & 0.93 & $\begin{array}{r}0.51 \\
1.69\end{array}$ & & $\S$ & $1 \cdot 14$ & $\begin{array}{r}0.82 \\
1.59\end{array}$ & $1 \cdot 34$ & $\begin{array}{c}0.92 \\
1.96\end{array}$ & & $-\S$ \\
\hline$P$ & & & & & & & & & & & & & & & & & & \\
\hline $\begin{array}{l}\text { Skin-prick test } \\
\text { positivity to } \\
\text { any allergen } \ddagger\end{array}$ & 0.82 & $\begin{array}{c}0.39 \\
1.72\end{array}$ & 0.79 & $\begin{array}{c}0.36 \\
1.75\end{array}$ & & $\S$ & 0.98 & $\begin{array}{r}0.66 \\
1.44\end{array}$ & 1.03 & $\begin{array}{r}0.67 \\
1.58\end{array}$ & & $\S$ & 1.33 & $\begin{array}{c}1.03 \\
1.72\end{array}$ & $1 \cdot 35$ & $\begin{array}{c}1.02 \\
1.79\end{array}$ & & $-\S$ \\
\hline$P$ & & & & & & & & & & & & & & & & & & \\
\hline $\begin{array}{l}\text { Doctor-diagnosed } \\
\text { asthmał }\end{array}$ & 0.94 & $\begin{array}{r}0.55 \\
1.60\end{array}$ & 1.06 & $\begin{array}{l}0.53 \\
2 \cdot 13\end{array}$ & & $\S$ & $1 \cdot 18$ & $\begin{array}{c}0.79 \\
1.77\end{array}$ & 1.35 & $\begin{array}{r}0.83 \\
2.17\end{array}$ & & $\S$ & $1 \cdot 12$ & $\begin{array}{r}0.80 \\
1.56\end{array}$ & 1.09 & $\begin{array}{c}0.76 \\
1.56\end{array}$ & & $-\S$ \\
\hline$P$ & & & & & & & & & & & & & & & & & & \\
\hline $\begin{array}{l}\text { PEF†ll } \\
\text { Coefficient }\end{array}$ & & & & & & 07 & & & & & & .02 & & & & & & .01 \\
\hline $95 \% \mathrm{Cl}$ & -0 & 0.39 & -0 . & 0.44 & -0. & 0.16 & & 0.09 & -0 & 0.07 & -0.0 & 0.01 & -0. & $0 \cdot 16$ & -0 & $0 \cdot 17$ & -0. & $2,0.04$ \\
\hline$P$ & & & & & & 14 & & & & & & 06 & & & & & & 429 \\
\hline $\mathrm{FEV}_{1} \dagger \|$ & & & & & & & & & & & & & & & & & & \\
\hline $\begin{array}{l}\text { Coefficient } \\
95 \% \mathrm{Cl}\end{array}$ & -0 & 0.30 & -0 & $\begin{array}{l}8 \\
0.29\end{array}$ & -0. & 3 & -0 & $\begin{array}{l}06 \\
0.02\end{array}$ & -0 & $\begin{array}{l}06 \\
0.02\end{array}$ & $\begin{array}{r}- \\
-0.0\end{array}$ & $\begin{array}{l}.03 \\
, 0.00\end{array}$ & -0 & $\begin{array}{l}02 \\
0.05\end{array}$ & -0 & $\begin{array}{l}01 \\
0.06\end{array}$ & -0 & $\begin{array}{l}0.00 \\
2,0.02\end{array}$ \\
\hline$P$ & & & & & & 03 & & & & & & 47 & & & & & & 813 \\
\hline $\mathrm{FVC+ \|}$ & & & & & & & & & & & & & & & & & & \\
\hline $\begin{array}{l}\text { Coefficient } \\
95 \% \mathrm{Cl}\end{array}$ & -0. & $\begin{array}{l}2 \\
0.29\end{array}$ & -0 & $\begin{array}{l}3 \\
0.29\end{array}$ & -0. & 0.06 & -0 & $\begin{array}{l}04 \\
0.22\end{array}$ & -0 & $\begin{array}{l}06 \\
0.01\end{array}$ & $\begin{array}{r}- \\
-0.0\end{array}$ & $\begin{array}{l}.02 \\
, 0.00\end{array}$ & -0 & $\begin{array}{l}.01 \\
0.05\end{array}$ & -0 & 1 & -0 & $\begin{array}{l}0.00 \\
2,0.02\end{array}$ \\
\hline$P$ & & & & & & 35 & & & & & & 19 & & & & & & 873 \\
\hline
\end{tabular}

F, ferritin; sTfR, soluble transferrin receptor; PEF, peak expiratory flow; $\mathrm{FEV}_{1}$, forced expiratory volume in the first second; FVC, forced vital capacity.

*Adjusted for maternal smoking status during pregnancy, birth order, maternal age, maternal Scottish Index of Multiple Deprivation, maternal atopic status, gestational age at birth and sex of child.

† Analysed using generalised estimating equations with an exchangeable correlation structure.

$\ddagger$ Analysed using discrete-time hazard models.

$\|$ Standardised $z$-score values of lung function measurements used in the analyses. 
liver $\mathrm{Fe}$ stores ${ }^{(23,39)}$. However, ferritin concentrations can increase as a result of inflammation and hence can give rise to falsely high values. Serum transferrin receptor concentrations increase during Fe deficiency, and the ratio of these two parameters gives the best estimate of $\mathrm{Fe}$ status ${ }^{(23,39)}$. Another strength of the present study is that the original cohort study was established to prospectively investigate the associations between maternal diet during pregnancy and childhood asthma and atopic disease and comprised healthy women recruited during pregnancy irrespective of asthma/ atopy and $\mathrm{Fe} / \mathrm{Hb}$ status. However, the present study sample is a subpopulation of the original cohort because financial considerations resulted in the number of mother-child pairs studied being small and the analysis being limited to those mother-child pairs with complete datasets during pregnancy and in the first 10 years of life. Women with Fe measurement data differed from those without these data, with regard to smoking status, age and socio-economic status, but not with regard to Fe supplement use, and at 10 years of age, children with $\mathrm{Fe}$ measurement data were found to less likely wheeze when compared with those without these data ( $9.0 v .12 .5 \%)$, although these differences were nonsignificant. These differences suggest that women without Fe measurement data were at a greater risk of developing Fe deficiency and their children more likely to wheeze. Such findings would bias any association between Fe and wheeze towards the null and the reported associations may lead to the underestimation of the associations between maternal Fe status and childhood outcomes.

In summary, this small nested cohort study is the first to demonstrate inverse associations between first-trimester serum Fe status and childhood wheeze and lung function. Inverse associations were found between maternal serum $\mathrm{Fe}$ status at delivery and childhood atopic outcomes consistent with those reported previously by the only study on maternal Fe status during pregnancy and childhood asthma and atopic outcomes. Because Fe replacement during pregnancy is relatively straightforward, the associations between maternal $\mathrm{Fe}$ status during pregnancy and childhood asthma and atopic disease warrant further investigation. In the first instance, the associations found in the present study and the ALSPAC require further replication in a larger prospective cohort study. It may be possible to follow up children born to women recruited to intervention studies of Fe replacement during pregnancy. Ultimately, a double-blind randomised controlled trial of Fe replacement during pregnancy with long-term follow-up of children will be required.

\section{Supplementary material}

To view supplementary material for this article, please visit http://dx.doi.org/10.1017/S0007114514003122

\section{Acknowledgements}

The present study was funded by Asthma UK (00/011, 02/017), the Medical Research Council (80219), and the University of Aberdeen's Development Trust.
The authors' contributions are as follows: K. A., N. P., H. H. and L. G. were involved in data acquisition and B. I. N. and G. D. performed the data analysis. All authors contributed to either the original or the present study hypothesis, the conception and design of the birth cohort, and/or the design and conduct of the cohort follow-up as well as to the writing and revision of this article.

None of the authors has any conflicts of interest to declare.

\section{References}

1. Godfrey KM, Barker DJP \& Osmond C (1994) Disproportionate fetal growth and raised $\operatorname{IgE}$ concentration in adult life. Clin Exp Allergy 24, 641-648.

2. Olesen AB, Ellingsen AR, Olesen H, et al. (1997) Atopic dermatitis and birth factors: historical follow up by record linkage. Br Med J 314, 1003-1008.

3. Shaheen SO, Sterne JAC, Montgomery SM, et al. (1999) Birth weight, body mass index and asthma in young adults. Thorax 54, 396-402.

4. Chatkin MN \& Menezes AM (2005) The association between low birthweight and asthma: a systematic literature review. Rev Panam Salud Publica 17, 102-109.

5. Pei L, Chen G, Mi J, et al. (2010) Low birth weight and lung function in adulthood: retrospective cohort study in China, 1948-1996. Pediatrics 125, e899-e905.

6. Orfei L, Strachan DP, Rudnicka AR, et al. (2008) Early influences on adult lung function in two national British cohorts. Arch Dis Childhood 93, 570-574.

7. Canoy D, Pekkanen J, Elliott P, et al. (2007) Early growth and adult respiratory function in men and women followed from the fetal period to adulthood. Thorax $\mathbf{6 2}$, 396-402.

8. Turner SW, Campbell D, Smith N, et al. (2010) Associations between fetal size, maternal $\alpha$-tocopherol and childhood asthma. Thorax 65, 391-397.

9. Turner S, Prabhu N, Danielian P, et al. (2011) First and second trimester fetal size and asthma outcomes at age ten years. Am J Respir Crit Care Med 184, 407-413.

10. Nurmatov U, Devereux G \& Sheikh A (2011) Nutrients and foods for the primary prevention of asthma and allergy: systematic review and meta-analysis. J Allergy Clin Immunol 127, 724-733.

11. Anandan C, Nurmatov U \& Sheikh A (2009) Omega 3 and 6 oils for primary prevention of allergic disease: systematic review and meta-analysis. Allergy 64, 840-848.

12. Devereux G \& Wagner JG (2011) Vitamin D and asthma: scientific promise and clinical reality. Curr Resp Med Rev 7 , 408-413.

13. Gambling L, Dunford S, Wallace DI, et al. (2003) Iron deficiency during pregnancy affects post-natal blood pressure in the rat. J Physiol 552, 603-610.

14. Shaheen SO, Newson RB, Henderson AJ, et al. (2004) Umbilical cord trace elements and minerals and risk of early childhood wheezing and eczema. Eur Respir $J$ 24, 292-297.

15. Martindale S, McNeill G, Devereux G, et al. (2005) Antioxidant intake in pregnancy in relation to wheeze and eczema in the first two years of life. Am J Respir Crit Care Med 171, 121-128.

16. Masson LF, McNeill G, Tomany JO, et al. (2003) Statistical approaches for assessing the relative validity of a food frequency questionnaire: use of correlation coefficients and the kappa statistic. Public Health Nutr 6, 313-321. 
17. Chitty LS, Altman DG, Henderson A, et al. (1994) Charts of fetal size: 4. Femur length. Br J Obstet Gynaecol 101, $132-135$.

18. Chitty LS, Altman DG, Henderson A, et al. (1994) Charts of fetal size: 2. Head measurements. Br J Obstet Gynaecol 101, 35-43.

19. Miller MR, Hankinson J, Brusasco V, et al. (2005) Standardisation of spirometry. Eur Respir J 26, 319-338.

20. Stanojevic S, Wade A, Stocks J, et al. (2008) Reference ranges for spirometry across all ages. Am J Respir Crit Care Med 177, 253-260.

21. Rigas AS, Sørensen CJ, Pedersen OB, et al. (2013) Predictors of iron levels in 14,737 Danish blood donors: results from the Danish Blood Donor Study. Transfusion 54, 789-796.

22. Cogswell ME, Parvanta I, Ickes L, et al. (2003) Iron supplementation during pregnancy, anemia, and birth weight: a randomized controlled trial. Am J Clin Nutr 78, 773-781.

23. Cook JD, Finch CA \& Smith NJ (1976) Evaluation of the iron status of a population. Blood 48, 449-455.

24. Willett WC, Howe GR \& Kushi LH (1997) Adjustment for total energy intake in epidemiologic Studies. Am J Clin Nutr 65, suppl., 1220S-1228S.

25. Nurmatov U, Nwaru BI, Devereux G, et al. (2012) Confounding and effect modification in studies of diet and childhood asthma and allergies. Allergy 67, 1041-1059.

26. Stern DA, Morgan WJ, Wright AL, et al. (2007) Poor airway function in early infancy and lung function by age 22 years: a non-selective longitudinal cohort study. Lancet 370, 758-764.

27. Groenman FA, Rutter M, Wang J, et al. (2007) Effect of chemical stabilizers of hypoxia-inducible factors on early lung development. Am J Physiol Lung Cell Mol Physiol 293, L557-L567.

28. Scholl TO \& Reilly T (2000) Anemia, iron and pregnancy outcome. J Nutr 130, 443S-447S

29. Alwan NA, Greenwood DC, Simpson NAB, et al. (2011) Dietary iron intake during early pregnancy and birth outcomes in a cohort of British women. Hum Reprod 26, 911-919.
30. Brion MJ, Leary SD, Smith GD, et al. (2008) Maternal anemia, iron intake in pregnancy, and offspring blood pressure in the Avon Longitudinal Study of Parents and Children. Am J Clin Nutr 88, 1126-1133.

31. Maazi H, Shirinbak S, Bloksma N, et al. (2011) Iron administration reduces airway hyperreactivity and eosinophilia in a mouse model of allergic asthma. Clin Exp Immunol 166 80-86.

32. Hale LP, Potts Kant E, Greer PK, et al. (2012) Iron supplementation decreases severity of allergic inflammation in murine lung. PLOS ONE 7, e45667.

33. Golub MS \& Hogrefe CE (2014) Prenatal iron deficiency and monoamine oxidase A (MAOA) polymorphisms: combined risk for later cognitive performance in rhesus monkeys. Genes Nutr 9, 381.

34. Golub MS, Hogrefe CE \& Germann SL (2007) Behavior of juvenile rhesus monkeys deprived of iron during fetal or infant development. J Nutr 137, 979-984.

35. Golub MS, Hogrefe CE, Germann SL, et al. (2005) Behavioral consequences of developmental iron deficiency in infant rhesus monkeys. Neurotoxicol Teratol 28, 3-17.

36. Golub MS, Hogrefe CE \& Unger EL (2012) Influence of prenatal iron deficiency and MAOA genotype on response to social challenge in rhesus monkey infants. Genes Brain Behav 11, 278-290.

37. Scientific Advisory Committee on Nutrition (2010) Iron and Health. London: The Stationery Office. http://www.sacn. gov.uk/pdfs/sacn_iron_and_health_report_web.pdf

38. Fosset C, McGaw B, Abramovich D, et al. (2004) Inter-relations between ceruloplasmin and $\mathrm{Fe}$ status during pregnancy. Biol Trace Elem Res 98, 1-12.

39. Sweet DG, Savage G, Tubman TRJ, et al. (2001) Study of maternal influences on fetal iron status at term using cord blood transferrin receptors. Arch Dis Child Fetal Neonatal Ed 84, F40-F43.

40. Chelchowska M \& Laskowska-Klita $T$ (2002) Effect of maternal smoking on some markers of iron status in umbilical cord blood. Rocz Akad Med Bialymst 47, 235-240. 